\title{
The effect of drying on the mechanical properties and structure of biodegradable films
}

\author{
Rosa, G. S. ${ }^{\text {a, b*}}$; Vanga, S. K. ${ }^{\text {b; Gariepy, Y. }{ }^{\text {; }} \text { Raghavan, V.- }}$ \\ ${ }^{a}$ Chemical Engineering, Federal University of Pampa, Bagé, Rio Grande do Sul, Brazil \\ bDepartment of Bioresource Engineering, McGill University, Ste-Anne-de-Bellevue, Quebec, Canada
}

*E-mail of the corresponding author: gabrielarosa@unipampa.edu.br

\begin{abstract}
The aim of this study was to investigate the effect of convective and vacuum drying on properties of biodegradable films. The film-forming solutions were prepared with bovine gelatin and carrageenan. The films solutions were dried in convective and vacuum dryers at temperatures of 40,50 and $60{ }^{\circ} \mathrm{C}$. The results of convective drying kinetics of biofilms showed a constant drying rate period followed by a falling drying rate period. The results of thickness showed dependence with moisture content present in films.Carrageenan films showed promising results, with high values of tensile strength and elongation for convective drying at $60^{\circ} \mathrm{C}$.
\end{abstract}

Keywords: gelatin; carrageenan; drying; biofilm

\section{Introduction}

The resulting environmental impact of the high consumption of plastic materials in the food industry has encouraged packaging industry to develop biodegradable packaging materials 
that can be used as substitutes for the current synthetic polymers [1]. The biopolymer based packaging films offers several advantages due to their good biodegradability, biocompatibility, environmentally-friendliness, and even edibility [2]. Biopolymer films have been generally classified according to the source of the original polymer utilized. Among the main raw materials, the polysaccharide-based or protein-based materials are the most widely used [3].

Gelatin is an animal protein extracted from skins, bones and connective tissue of animals by controlled hydrolysis of the fibrous insoluble collagen [4;5]. It is well known that gelatin has been widely used in food industries due to its film-forming ability and its use as an outer film to protect food from drying and exposure to light and oxygen [6]. Carrageenans are natural and water soluble sulfated polysaccharides extracted from red seaweeds [7]. The differences in the chemical structure of carrageenans are essential for their physicochemical properties and the helical structure formation leading to varied applications [8]. Park (1996) [9] reported that Kappa-carrageenan is able to produce a clear film with excellent mechanical and structural properties with high tensile strength.

In order to produce efficient packaging films, the properties of films must be optimized for commercial applications. The formation of polymeric films occurs during solvent evaporation and includes complex heat and mass transfer phenomena and polymeric chain reorganization [10]. Several researchers reported on the influence of drying conditions on the mechanical and barrier properties of alginate, whey protein, chitosan, gelatin biofilms [11; $12 ; 13 ; 14]$. However, the literature does not show results of impact of drying on carrageenan films. The aim of this study was to investigate the effect of convective and vacuum drying on properties of biodegradable films produced from bovine gelatin and carrageenan.

\section{Materials and Methods}

\subsection{Materials}

Gelatin from bovine skin and kappa-carrageenan were used as biopolymeric matrix while glycerol (analytical grade) was used as a plasticizer. All reagents were obtained from SigmaAldrich (USA); distilled water was available in the laboratory for preparation of all solutions.

\subsection{Biofilm formation and Drying}

Gelatin and carrageenan films were produced by the casting method, using the methodology proposed by Martiny [15]. The convective drying of films was performed in a custom made laboratory convective hot-air dryer. The perpendicular air flow coming from the blower was heated by an electrical heater. The inlet and outlet air temperatures were measured outside the shielded cavity using type-T thermocouples. The convective drying conditions were 40, 50 and $60{ }^{\circ} \mathrm{C}$ at an air velocity of one $\mathrm{m} / \mathrm{s}$. The drying curves $\left(\left(M-M_{e}\right) /\left(M_{0}-M_{e}\right)\right.$ as a function of time) were obtained. The equilibrium moisture content was assumed as the final moisture 
content, when the drying rate was practically null, at each drying condition. The drying rates were determined using Equation 1.

$$
\mathrm{R}=-\frac{L_{s}}{A} \cdot \frac{d M}{d t}
$$

where, $\mathrm{R}$ is the drying rate $\left(\mathrm{kg} \cdot \mathrm{h}^{-1} \cdot \mathrm{m}^{-2}\right), L_{s}$ is dried solids mass $(\mathrm{kg}), A$ is drying area $\left(\mathrm{m}^{2}\right), M$ is the moisture content (kg.kg-1, d.b.) and $t$ is time (h).

The vaccum drying of films was performed in a vaccum oven (StableTemp, Cole-Parmer, USA) with controlled temperature connected with vaccum line (25” Hg) for $48 \mathrm{~h}$. The same temperatures studied in convective dryer $\left(40,50\right.$ and $\left.60^{\circ} \mathrm{C}\right)$ were applied for vaccum drying.

\subsection{Biofilm characterization}

The biofilm thickness was measured using a electronic digital micrometer (Marathon Co, CO030025, Canada) with $0.001 \mathrm{~mm}$ of resolution. Mean thickness was calculated from ten measurements taken at different locations on biofilm samples, according to Ferreira et al. [16]. Water vapor permeability (WVP) of biofilms was determined gravimetrically using the ASTM standard method E96/E96M-05 [17]. Tensile strength (TS) and elongation percentage (E) at break point were measured uniaxially by stretching the specimen in one direction using a Universal Testing Machine (50 N load cell - Instron 4502, USA) according to the ASTM standard method D-882-02 [18] . Scanning electron micrographs (SEM) of the film samples submitted to different drying temperatures and methods were obtained using a scanning electron microscope (Hitachi, TM 3000, Japan). Experimental data were analyzed by Statistica 7.1 software. Mean comparasions were carried out by Tukey test ( $p<0.05$ was considered as significant).

\section{Results and Discussion}

Typical drying curves obtained are illustrated in Figure 1. Overall drying kinetic curves obtained for biofilms samples under different drying conditions showed the same behavior. In all experiments, the drying kinetics of biofilms showed a constant drying rate period followed by a falling drying rate period. The drying of high moisture materials typically presents a constant drying rate period and one or two falling rate periods [19].The moisture contents of the samples at the end of the drying process were in the range of 0.2 to $1.8 \mathrm{~g} . \mathrm{g}^{-1}$ (d.b.) and the time taken to reach the final moisture content $\left(M_{e}\right)$ increased from 234 min to $360 \mathrm{~min}$. 

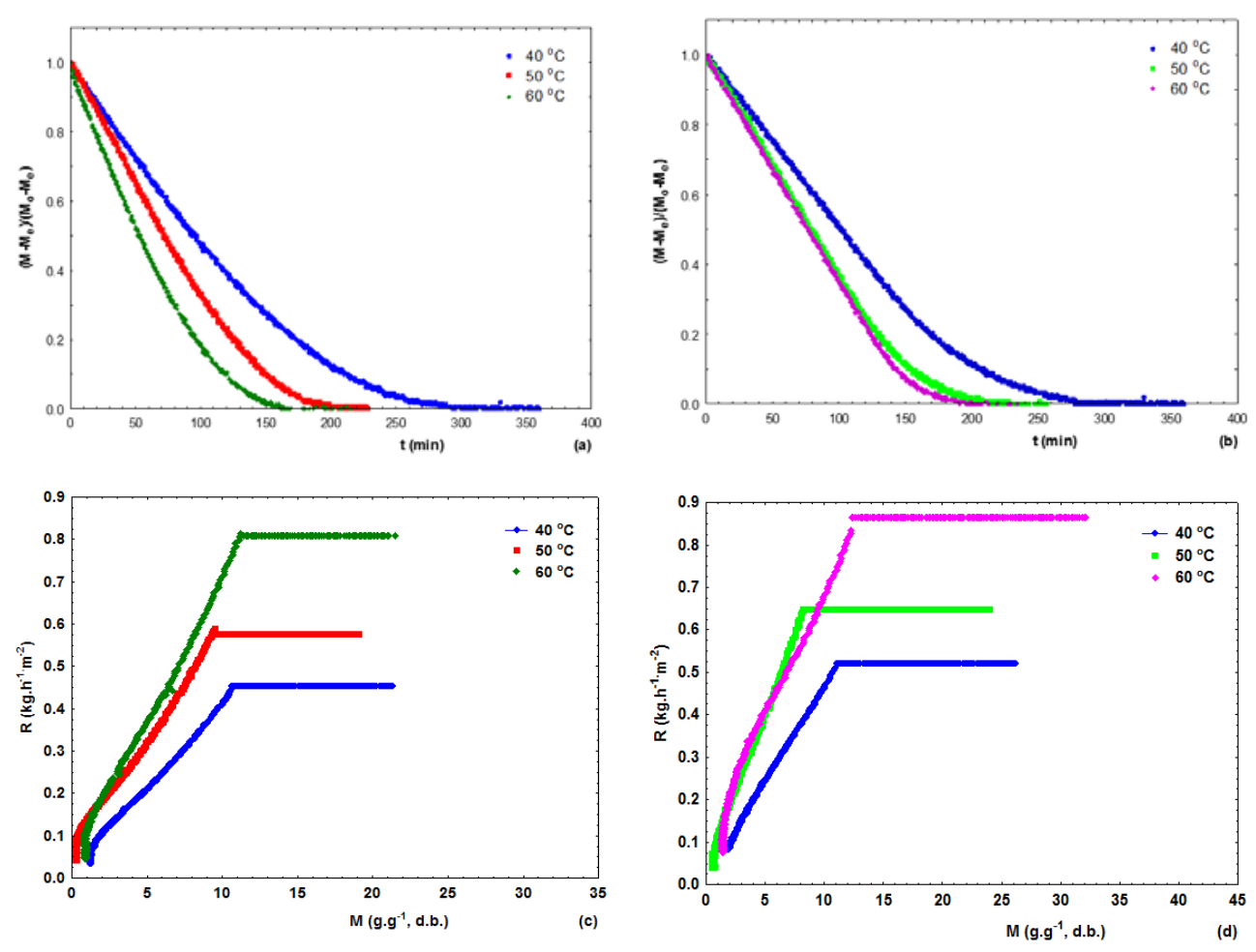

Fig. 1 Drying curves of biofilms at diferent operation conditions:

(a) and (c) gelatin films; (b) and (d) carrageenan films.

As the moisture content of the samples was very high during the initial phase of the drying, higher drying rates were observed. As the drying progressed, the moisture loss (solventwater) from the product resulted in the fall of drying rate. Various studies also reported that drying curves of polymers dispersed in solvents showed an initial period of constant drying rate before the falling rate period [19; 20; 21]. During the falling rate period, water movement may occur in the films via liquid diffusion, which is driven by moisture gradients, and vapor diffusion. This is enhanced by the vapor partial pressure gradients induced by the temperature gradients. Because pores were not observed in the SEM micrographs of film (Figure 2), liquid movement via capillarity is less probable [22; 19].

Table 1 shows the values obtained for thickness, water vapor permeability (WVP), tensile strength (TS) and elongation (E) of the gelatin and carrageenan biofilms. 
Table 1. Physical and mechanical properties of gelatin and carrageenan films.

\begin{tabular}{|c|c|c|c|c|}
\hline & $\begin{array}{l}\text { Thickness } \\
(\mathrm{mm})\end{array}$ & $\begin{array}{c}\text { WVP } \\
\left(\text { g.m } \mathrm{m}^{-1} \cdot \mathrm{s}^{-1} \cdot \mathrm{Pa}^{-1}\right)\end{array}$ & $\begin{array}{c}\mathrm{TS} \\
(\mathrm{MPa})\end{array}$ & $\begin{array}{c}\mathrm{E} \\
(\%)\end{array}$ \\
\hline G-Conv $40^{\circ} \mathrm{C}$ & $0,122 \pm 0,007^{\mathrm{bc}}$ & $1,99 \cdot 10^{-10} \pm 3,80 \cdot 10^{-12} \mathrm{c}$ & $24,50 \pm 3,58^{\mathrm{ab}}$ & $80,76 \pm 8,92^{\mathrm{ab}}$ \\
\hline G-Conv $50^{\circ} \mathrm{C}$ & $0,100 \pm 0,007^{\mathrm{ab}}$ & $1,47 \cdot 10^{-10} \pm 4,91 \cdot 10^{-12 \mathrm{ab}}$ & $30,19 \pm 2,11^{\mathrm{b}}$ & $128,56 \pm 21,12^{b}$ \\
\hline G-Conv $60^{\circ} \mathrm{C}$ & $0,128 \pm 0,016^{c}$ & $1,91 \cdot 10^{-10} \pm 5,76 \cdot 10^{-12 b c}$ & $21,10 \pm 5,61^{\mathrm{ab}}$ & $115,84 \pm 28,96^{b}$ \\
\hline G-Vacc $40^{\circ} \mathrm{C}$ & $0,106 \pm 0,003^{\mathrm{abc}}$ & $1,47.10^{-10} \pm 1,83 \cdot 10^{-11} \mathrm{ab}$ & $28,17 \pm 7,84^{b}$ & $68,10 \pm 2,80^{\mathrm{ab}}$ \\
\hline $\mathrm{G}$-Vacc $50^{\circ} \mathrm{C}$ & $0,090 \pm 0,008^{\mathrm{a}}$ & $1,38.10^{-10} \pm 4,3$ & $13,86 \pm 3,75^{\mathrm{a}}$ & $19,16 \pm 3,08^{\mathrm{a}}$ \\
\hline G-Vacc $60^{\circ} \mathrm{C}$ & $0,080 \pm 0,008^{\mathrm{a}}$ & $1,32 \cdot 10^{-10} \pm 1,35 \cdot 10^{-12} \mathrm{a}$ & $12,19 \pm 2,04^{\mathrm{a}}$ & $25,57 \pm 6,53^{\mathrm{a}}$ \\
\hline C-Conv $40^{\circ} \mathrm{C}$ & $0,081 \pm 0,002^{\mathrm{bc}}$ & $1,32 \cdot 10^{-10} \pm 2,34 \cdot 10^{-12} \mathrm{ab}$ & $41,48 \pm 0,85^{\mathrm{ab}}$ & $64,49 \pm 5,06^{\text {ab }}$ \\
\hline C-Conv $50^{\circ} \mathrm{C}$ & $0,089 \pm 0,004^{\mathrm{a}}$ & $1,38.10^{-10} \pm 1,65.10^{-12} \mathrm{a}$ & $37,73 \pm 4,99^{\mathrm{a}}$ & $80,66 \pm 8,11^{b}$ \\
\hline C-Conv $60^{\circ} \mathrm{C}$ & $0,087 \pm 0,004^{\mathrm{ab}}$ & $1,421 \cdot 10^{-10} \pm 4,05 \cdot 10^{-12 \mathrm{a}}$ & $42,63 \pm 5,64^{\mathrm{ab}}$ & $68,69 \pm 13,62^{\mathrm{ab}}$ \\
\hline $\mathrm{C}$-Vacc $40^{\circ} \mathrm{C}$ & $0,089 \pm 0,003^{\mathrm{a}}$ & $1,35 \cdot 10^{-10} \pm 4,94 \cdot 10^{-13}$ a & $48,26 \pm 3,46^{\text {ab }}$ & $69,82 \pm 4,25^{\mathrm{ab}}$ \\
\hline $\mathrm{C}-$ Vacc $50^{\circ} \mathrm{C}$ & $0,074 \pm 0,007^{c}$ & $1,20.10^{-10} \pm 2,10.10^{-12} \mathrm{~b}$ & $54,44 \pm 3,16^{\mathrm{b}}$ & $62,42 \pm 1,14^{\mathrm{a}}$ \\
\hline C-Vacc $60^{\circ} \mathrm{C}$ & $0,087 \pm 0,004^{\mathrm{ab}}$ & $1,42 \cdot 10^{-10} \pm 2,03 \cdot 10^{-12} \mathrm{a}$ & $44,78 \pm 3,31^{\mathrm{ab}}$ & $56,89 \pm 3,59^{\mathrm{ab}}$ \\
\hline
\end{tabular}

Average \pm deviation ( $n=10$ for thickness, $n=2$ for WVP, $n=3$ for mechanical properties)

Different letters in the same column (separated gelatin (G-) and carrageenan (C-) films) indicate significant differences between samples $(\mathrm{p}<0.05)$

The film thicknesses were in the range of 0.074 to $0.128 \mathrm{~mm}$ and showed significant difference $(p>0.05)$ regarding films obtained from diferents drying methods and temperatures. Ahmad et al. [23] reported that the thickness depends on the components and the water content in film structure. Gelatin biofilms obtained showed properties similar to those published by other authors. Nishihora [24] reported a thickness of $0.086 \mathrm{~mm}$ and WVP of $1.82 .10^{-10} \mathrm{~g} \cdot \mathrm{m}^{-1} \cdot \mathrm{s}^{-1} \cdot \mathrm{Pa}^{-1}$; Albertos et al. [25] reported WVP of $2.10^{-10} \mathrm{~g} \cdot \mathrm{m}^{-1} \cdot \mathrm{s}^{-1} \cdot \mathrm{Pa}^{-1}$; Bertan [26] showed thickness values between 0.075 and $0.128 \mathrm{~mm}$; Musso et al. [27] reported a WVP from $6.5 .10^{-10}$ to $7.9 \cdot 10^{-10} \mathrm{~g} \cdot \mathrm{m}^{-1} \cdot \mathrm{s}^{-1} \cdot \mathrm{Pa}^{-1}$, tensile strength from 3.4 to $4.6 \mathrm{MPa}$ and elongation between 159 to $206 \%$. 
Martins et al. [28] produced carrageenan films and obtained thickness of $0.052 \mathrm{~mm}, 16.18 \%$ elongation and 19.95 MPa for tensile strength. Several studies with carrageenan films have shown WVP from $5.8 \cdot 10^{-11}$ to $2 \cdot 18 \cdot 10^{-8} \mathrm{~g} \cdot \mathrm{m}^{-1} \cdot \mathrm{s}^{-1} \cdot \mathrm{Pa}^{-1}$ [28; 29; 30; 31; 32; 33], tensile strength from 11.64 to $26.29 \mathrm{MPa}$ and elongation from 2.54 to $45 \%$ [28; 31; 33; 34].

The data reported in the literature for tensile strength and elongation are smaller than those obtained in this work. This was attributed to the differences in the preparation, composition and proportions of the film-forming solutions. Results for carrageenan films looked promising. Normally, a high tensile strength in the formulated film is common, however the flexibility of the film, indicated by the elongation is a very important parameter. This enables better applicability of this film in packaging [35].

There were no significant difference $(\mathrm{p}<0.05)$ between the WVP, tensile strength and elongation of carrageenan biofilms obtained from convective drying. Also, gelatin biofilms obtained from convective drying did not show significant difference for tensile strength and elongation. This is a desirable since the convective drying can be faster when the temperature is $60^{\circ} \mathrm{C}$.

SEM images of gelatin and carrageenan films are shown in Figure 2. Among the films, the gelatin films were more homogeneous and transparent, while the carrageenan film had the highest density of clusters and the highest opacity. These images show smooth and homogeneous surfaces for gelatin films. Despite the carrageenan films showing a heterogeneous surface, it was not possible to see defects and cracks. The non-uniformity of carrageenan films was attributed to the early gelation during casting [31].

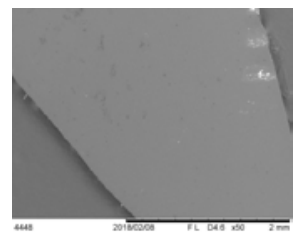

(a)

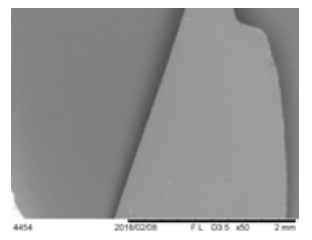

(b)

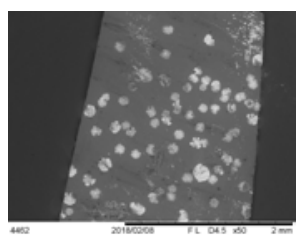

(c)

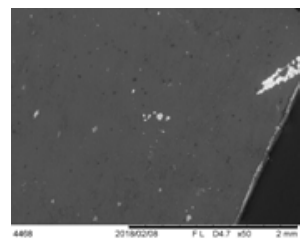

(d)

Fig. 2 SEM micrographs of surface of films obtained from (a) gelatin-convective drying at $50^{\circ} \mathrm{C}$, (b) gelatin-vaccum drying at $50^{\circ} \mathrm{C}$, (c) carrageenan-convective drying at $50^{\circ} \mathrm{C}$, (d) carrageenanvaccum drying at $50^{\circ} \mathrm{C}$.

\section{Conclusions}

The development of this research allowed to investigate the effect of convective and vacuum drying on properties of gelatin and carrageenan films. The convective drying kinetics showed a constant drying rate period followed by a falling drying rate period, wich is typical of materials with high moisture content. The results of thickness showed dependence with 
moisture content present in films. Carrageenan films showed promising results, with high values of tensile strength and elongation even for those made in the convective dryer at 60 ${ }^{\circ} \mathrm{C}$.

\section{Acknowledgements}

The authors would like to thank Coordination for the Improvement of Higher Education Personnel (CAPES) and Natural Sciences and Engineering Research Council of Canada (NSERC) for the financial support.

\section{References}

[1] Rhim, J.W. Mechanical and water barrier properties of biopolyester films prepared by thermo-compression. Food Science and Biotechnology 2007, 16 (1), 62-66.

[2] Salmieri. S.: Lacroix. L. Phvsicochemical Properties of Alginate/Polycaprolactone-Based Films Containing Essential Oils. J. Agric. Food Chem. 2006, 56, 10205-10214.

[3] Park, H.; Byun, Y.; Kim, Y.; Whiteside, W.; Bae, H. Innovations in food packaging (2nd ed.). Processes and applications for edible coating and film materials from agropolymers. Academic Press, 2014.

[4] Karim, A.A.; Bhat, R. Gelatin alternatives for the food industry: Recent development challenges and prospects. Trends in Food Science \& Tehcnology 2008, 19, 644-656.

[5] Patil, R.D.; Mark, J.E.; Apostolov, A.; Vassileva, E.; Fakirov, S. Crystallization of water in some crosslinked gelatins. European Polymer Journal 2000, 36 (5), 1055-1061.

[6] Arvanitoyannis, I.S. Formation and properties of collagen and gelatine films and coating. In A. Gennadios (Ed.), Protein-based films and coating. Boca Raton: Florida, 2002, 275302.

[7] Campo, V.L.; Kawano, D.F.; Silva, D.B.; Carvalho, I. Carrageenans: Biological properties, chemical modifications and structural analysise A review. Carbohydrate Polymers 2009, 77, 167-180.

[8] De Ruiter, G.A.; Rudolph, B. Carrageenan biotechnology. Trends in Food Science \& Technology 1997, 8, 389-395.

[9] Park, H. Gas and mechanical barrier properties of carrageenan-basedbiopolymer films. Food Science and Industry 1996, 29, 47-53.

[10] Putranto, A.; Chen, X.D.; Webley, P.A. Infrared and convective drying of thin layer of polyvinyl alcohol (PVA)/glycerol/water mixturedThe reaction engineering approach (REA). Chemical Engineering and Processing 2010, 49, 348-357.

[11] Da Silva,M.A.; Bierhalz, A.C.K.; Kieckbush, T.G. Influence of drying conditions on physical properties of alginate films. Drying Technology 2012, 30, 72-79.

[12] Denavi, G.; Tapia-Blácido, D.R.; Añón, M.C.; Sobral, P.J.A.; Mauri, A.N.; Menegalli, F.C. Effects of drying conditions on some physical properties of soy protein films. Journal of Food Engineering 2009, 90, 341-349

[13] Fernández-Pan, I.; Ziani, K.; Pedroza-Islas, R.; Maté, J.I. Effect of drying conditions on the mechanical and barrier properties of films based on chitosan. Drying Technology 2010, 28, 1350-1358.

[14] Menegalli, F.C.; Sobral, P.J.A.; Roques, M.A.; Laurent, S. Characteristics of gelatin biofilms in relation to drying process conditions near melting. Drying Technology 1999, 17, 1697-1706

[15] Martiny, T.R. Development of biodegradable films based on gelatine and carrageenans of the red algae gigartina skottsbergii incorporated with fluid extract of olive leaves. 137 p. MSc.(Master in Engineering), Federal University of Pampa , 2017

[16] Ferreira, C.O.; Nunes, C.A.; Delgadillo, I.; Silva, J.L. Characterization of chitosan whey-protein films at acid pH, Food Res. Int. 2009, 42, 807-813. 
[17] ASTM. Standard methods of water vapor transmission of materials. Method: E96/ E96M05. Philadelphia: American Society for Testing Materials, 2005.

[18] ASTM. Standard test methods for tensile properties on thin plastic sheeting. Method: D 882. Philadelphia: American Society for Testing Materials, 2002.

[19] Moraes, J.O; Scheibe, A.S.; Carciofi, B.A.M.; Laurindo, J.B.; Conductive drying of starch-fiber films prepared by tape casting: Drying rates and film properties, LWT - Food Science and Technology 2015, 64, 356-366.

[20] Stupa, M.V.; Platonov, E.K.; Milkhailov, V.T. Mathematical model of drying of granulated anid. Fibre Chemistry, 2003, 35, 233-236.

[21] Karapantsios, T.D. Conductive drying kinetics of pregelatinized starch thin films. Journal of Food Engineering 2006, 76(4), 477-489.

[22] Kerr, W.L. Food drying and evaporation processing operations. Handbook of Farm Dairy, and Food Machinery 2007, 303-340

[23] Ahmad, M.; Hani, N.M.; Nirmal, N.P.; Fazial, F.F.; Mohtar, N.F.; Romli, S.R. Progress Org. Coating 2015, 84, 115-127.

[24] Nishihora, R.K. Properties of crosslinked gelatin films by enzymatic and physical route. 96 p. MSc. (Master in Chemical Engineering), Federal University of Santa Catarina, 2015.

[25] Albertos, I.; Avena-Bustillos, R.J.; Martín-Diana, A.B.; Dub, W.X.; Rico, D.; McHugh, T.H. Antimicrobial Olive Leaf Gelatin films for enhancing the quality of coldsmoked Salmon Food Packaging and Shelf Life 2017, 13, 49-55

[26] Bertan, L.C. Development and characterization of biofilms based on polymers from renewable sources and its application in the packaging of bread of form. $188 \mathrm{p}$. PhD (Teshis in Food Technology), State University of Campinas, 2008.

[27] Musso, Y.S.; Salgado, P.R.; Mauri, A.N. Smart edible films based on gelatin and curcumin Food Hydrocolloids 2017, 66 8-15.

[28] Martins, J.T.; Cerqueira, M.A.; Bourbon, A.I.; Pinheiro, A.C.; Souza, B.W.S.; Vicente, A.A. Synergistic effects between k-carrageenan and locust bean gum on physicochemical properties of edible films made thereof. Elsevier, Food Hydrocolloids, v. 29, p. 280-289, 2012.

[29] Karbowiak, T.; Debeaufort, F.; Champion, D.; Voilley, A. Effect of Plasticizers (Water and Glycerol) on the Diffusion of a Small Molecule in Iota-Carrageenan Biopolymer Films for Edible Coating Application. Biomacromolecules 2006, 7, 2011-2019.

[30] Larotonda, F.D.S. Biodegradable films and coatings obtained from carrageenan from Mastocarpus stellatus and starch from Quercussuber. Faculty of Engineering of the University of Porto. Ph.D thesis, 2007..

[31] Paula, G.A.; Benevides, N.M.B.; Cunha, A.P.; Oliveira, A.V.; Pinto, A.M.B.; Morais, J.P.S.; Azeredo, H.M.C. Development and characterization of edible films from mixtures of $\kappa$-carrageenan, 1 -carrageenan and alginate. Elsevier, Food Hydrocolloids 2015, 47, 140-145.

[32] Rhim, J.W. Physical-Mechanical Properties of Agar/א-Carrageenan Blend Film and Derived Clay Nanocomposite Film. Journal of Food Science 2012,. 77 (12), 66-73.

[33] Shojaee-Aliabadi, S.; Hosseini, H.; Mohammadifar, M.A.; Mohammadi, A.; Ghasemlou, M.; Hosseini, S.M.; Khaksar, R.Characterization of k-carrageenan films incorporated plant essential oils with improved antimicrobial activity. Carbohydrate Polymers 2014, 101, 582-591.

[34] Cha, D.S.; Choi, J.H.; Chinnan, M.S.; Park, H.J.Antimicrobial Films Based on Naalginate and k-carrageenan. Lebensmittel-Wissenschaft and Technologie (LWT) 2002, 35, 715-719.

[35] Kim, Y.T; Min, B.; Kim, K.W. General Characteristics of Packaging Materials for Food System. Innovations in Food Packaging: Second Edition. Elsevier, 2013. 